\title{
Memory Watchdogs. Online and Offline Mobilizations around Controversial Historical Issues in Russia
}

\author{
Elena Perrier (Morenkova)
}

In our country we are only starting - only now! - the real process of rethinking of our history. And the role of Stalin in this history is not yet defined in collective consciousness. We need to talk a lot to each other (...). And the Victory day is the right time for such a conversation ${ }^{1}$.

During the Soviet period, the Victory of the USSR in the Great Patriotic War over German invaders was both a "civic religion", the main symbol of the regime, exploited by State propagandists and the only real holiday and memorial day for millions of citizens (Tumarkin 1994, 24). Starting from the Thaw and more openly starting from the period of glasnost', two conflicting versions of the Great Patriotic War coexisted in public discourse and cultural memory in Russia: the officially approved version ("the glorious history") and the alternative version ("the truth from the trenches"). Those two versions presented not only different interpretations of the role of the USSR in the Second World War, but also two different attitudes towards historical Stalinism. The first one is the memory of the Victory, eliminating the question of its price and concentrating on the heroic side; the second is the memory of hardships, large number of victims, imprisonments, evacuation and collaboration, but also of secret protocols of Molotov-Ribbentrop pact, that divided territories of Eastern Europe into the Nazi and the Soviet spheres of influence. The former emphasizes a patriotic consensus between the Communist Party and the Soviet People ("For Motherland! For Stalin!"), the latter is intertwined with the memory of the terror and thus is intrinsically anti-Stalinist (Roginskii 2009). The omission of Soviet - Nazi relations before 1941 from the glorious narrative serves to replace

1 'Leonid_b' (March 9, 2010). 'Tipa tol'ko voprosy'/'Sort of just questions', Livejournal. Accessed January 1, 2014. <http://leonid-b.livejournal.com/667464.html?thread=13840712\#t13840712>.

(C) ELENA PERRIER (MORENKOVA), 2019| DOI:10.1163/9789004366671_008

This is an open access chapter distributed under the terms of the prevailing CC-BY-NC-ND License. 
the Second World War history by the one of Great Patriotic War, which started, according to this version, on June 22, 1941 with the sudden and perfidious aggression ("verolomnoe napadenie") of the USSR by Nazi Germany².

Under Brezhnev, the cult of the Great Patriotic War comes along with the rampant rehabilitation of Stalin. However, banned from the public discourse at the end of the 196os, the "dissident" memory comes back to light during the period of glasnost' at the end of the 1980 - beginning of 1990. The wave of destalinization led to a critical re-examination of the official Soviet Great Patriotic War narrative as a part of an unprecedented historical re-evaluation. The glorious version was challenged from all sides: we can, for example, mention Viktor Suvorov's ${ }^{3}$ large audience historical books, such as his bestsellers Ledokol or Day M, making parallels between Stalin and Hitler and concentrating on their relations before 1941; the wave of samizdat and tamizdat; or the outbreak of the oral history in the press. Besides, the post-Soviet elites, former apparatchiks in their majority, wanted to highlight their break with the "dark past" and its symbols by denigrating the Soviet past and claiming their opposition to Communism (Smith 1996; 2002). In those conditions, the sumptuous commemorations of "megaholiday" of the Victory Day were temporarily suspended (Tumarkin 1994; Andreev, Bordugov 2005).

However, the drive for destalinization lost ground in the mid-199o with the rise of a new "revamped patriotic ethic" (Smith 2002, 57). Since the second half of the 1990s, the theme of national revival has crystallized in Russia, notably in the form of promoting patriotism rooted in the glorious version of the war (Daucé, Désert et al. 2010). In 1995, the Parliament adopted a bill "On the immortalization of the Victory of the Soviet people in the Great Patriotic War of 1941-1945", ${ }^{4}$ marking the transition to an "era of commemorations": Victory Day had its status confirmed as the principal national day, and is more solemnly celebrated now than it used to even during Soviet times (Andreev, Bordiugov 2005).

This tendency strengthened in the 2000s, when the symbol of the Victory became both the cornerstone of Putin's regime and the foundation of national

2 For the « canonical » Soviet version of the Great Patriotic War, one can refer to the following classic work edited by the Communist Party Central Committee: Pospelov, Petr (ed.) (19601965), Istoriya Velikoi Otechestvennoi Voiny Sovetskogo Soyuza 1941-1945 v chesti tomakh/History of the Great Patriotic War of Soviet Union in six volumes, 1941-1945 (Moscow: Institute of Marxism - Leninism of Central Committee of CPSU).

3 Soviet military intelligence officer and author of historical bestsellers as Ledokol or Day M, making parallels between Stalin and Hitler.

4 Federal bill n ${ }^{\circ}$ 80-FZ of May 19, 1995 'Ob uvekovechenii pobedy sovetskogo naroda v Velikoi Otechestvennoi Voine 1941-1945', <http://www.referent.ru/1/14905>, accessed January 10, 2014. 
self-identification (Etkind 2009; Gudkov 2005; Roginskii 2009). The reason for that is twofold. On the one hand, the Russian population strives for positive symbols rooted in its national history: in 2005, $87 \%$ of Russians placed the Victory at the top of the list of events in Russian history of which they were particularly proud, while in 1996, this percentage was no higher than $44 \%$ (Gudkov 2005,98 ). This demand for positive narratives could be explained by socialpsychological factors such as feeling of collective humiliation due to the defeat in the Cold War and the breakdown of the Soviet empire (Dubin 2011). On the other hand, the instrumentalisation of the Victory constitutes one of the tools of current regime symbolic policies. Current research emphasizes the convergence between an offer "from above" and a demand "from below" of a new patriotic narrative rooted in the Great Patriotic War: the political strategy seemed to converge upon more broad cultural discourse (Nivat 2008; Adler 2012).

However, this revaluation of the Great Patriotic War raises an issue of reintroducing into the commemorative space one of the most controversial figures in Russian history, i.e. Joseph Stalin: since the two symbols are intertwined, the rebirth of the Victory mythology requires the clarification of Russia's relation to the historical Stalinism. This issue remains one of the most controversial in current cultural debate, mainly because of the failed memory work and the absence of significant measures of transitional justice at the beginning of the 1990s. Due to the absence of any clear social, legal and even historical interpretation of Stalin and Stalinism in Russia, both Russian state and society have adopted an ambiguous attitude to Stalin in the years 2000. The unclear attitude of current political leadership in Russia towards Stalin is evident from the contradictory discourse and memory polices, simultaneously rehabilitating the Stalinist version of the Great Patriotic War and trying to keep a distance with historical Stalinism. The creation of the Presidential Commission to Counter Attempt to Falsify History to the Detriment of Russia's Interests in 2009, promoting the "patriotic" version of the Great Patriotic War in its Stalinist version and the "Destalinization Commission" 5 in 2011 that launched the third wave of destalinization of Russia is just one of the illustrations of this ambiguity. As for the cultural memory, it is also ambivalent. While the memory of the darker sides of the war (notably, the division of Eastern Europe by Stalin and Hitler, the errors of Soviet leaders, but also the concentration camp universe of the rear echelon, the collaborations, etc.) appears to vanish away with the

5 The Commission was formed on a basis of the program "On the perpetuation of the memory of victims of the totalitarian regime" prepared by the Working Group on Historical Memory of the Presidential Council for Civil Society Development and Human Rights in February, 2011. 
generational change (Veselova 2004), and the symbol of the Great Patriotic War seems consensual, Stalin remains a highly controversial figure, perceived as both "chief of Victory" and "tyrant" (Levada, 2004).

The clumsy efforts to keep and instrumentalise the glorious memory of Victory and not to assume explicitly Stalin's heritage are regularly accentuated on the occasion of the Victory day, triggering debates that emphasize the problematic character of the symbol: what was exactly the role of Stalin in the Great Patriotic War? Can his image be associated with the symbol of the Victory and to what extent? And, in more broad terms, can one be separated from another without a complete re-evaluation of the Russian history and, hence, of the fragile post-Soviet identity? This tension between two intertwined symbols forms the central focus of this chapter as it explores heated debates over Stalin's role in the Victory on the occasion of 2010 Victory commemoration in Russian online communities, online and offline mobilisations generated by this controversial issue, as well as their sustainability.

It pays however to remind in this regard that the Ukrainian crisis that started in 2014 has significantly reinforced the positive attitude to Stalin and Stalinism in Russia, as well as it has boosted the government's policies aiming to glorify Stalin: in February 2015, Russian authorities inaugurated, in the region of Crimea, a 10-tones bronze sculpture of the Yalta's 1945 conference "Big Three", Stalin, Churchill and Roosevelt (Radio Liberty, 2015). A month later, a museum honouring Stalin and his legacy sets to be opened in Russia in 2015, as a result of an initiative of Russian Military-Historical Society, headed by Minister of Culture Vladimir Medinskii (TheMoscowTimes 2015). ${ }^{6}$ While this dynamic illustrates a thrive of an imperial sentiment in Russia up from the beginning of military conflict in Ukraine, it should be considered as an epidemic reaction provoked by heavy patriotic propaganda. In the normal course, Stalin remains a controversial figure of Russian history, and the opinion of Russian population as well as elites' is split on this particular matter. In the beginning of 2010, the year our research was carried out, the controversies about Stalin's legacy were particularly emotional.

\section{Online Communities: New Actors in Memory Games}

While the traditional debate on those issues, both academic and popular, remains stirring, the introduction of social media has now offered an opportu-

6 More about the activities of Medinskii and the Ministry of Culture headed by him see the chapter by Jonson in this volume. 
nity for the opinions to be communicated online by non-academic commentators, allowing the more active part of society to engage in discussions concerning the controversial issues in the national memory and history. This chapter aims to analyse the debate on the social memory of the role of Stalin in Second World War in post-Soviet Russia by exploring new memory practices and new forms of civic memory activism facilitated by dissemination of internet in Russia. Although the Great Patriotic War memory in post-Soviet Russia has featured in research, and although internet debates on national history are a part of wider cultural debate, limited attention has been paid to how those issues are discussed within online communities, in particular in the light of ambiguous attitude of Russian authorities and society to historical Stalinism. Posing a set of questions concerning the emergency of new actors in the national memory space who engage with social media (internet memory activists, or internet "watchdogs/guardians of memory"), my research will develop a threefold argument.

I will first argue that new memory spaces and actors are emerging within the Runet as a reaction to certain memory policies ("memory watchdogs"), perceived as attempts to "re-stalinize" or "de-stalinize" the Great Patriotic War narrative. In the case explored, two contradictory public authorities' decisions (namely, to introduce and to remove Stalin from the Great Patriotic War commemorative space and narrative) triggered fierce debate and mobilizations, both online and offline, thus exemplifying a public desire to construct a space of counter history and counter memory, challenging the official memory policies.

I will then argue that the reaction of "memory watchdogs" and social media users to memory initiatives of central or local authorities emphasizes the conflicting nature of the Great Patriotic War issue as related to the memory of Stalin, bringing to light the complex attitude towards historical Stalinism in contemporary Russian society. The link made between Stalin and the image of Victory in the Russian cultural memory is highly controversial: the image of "victor" competes with the image of "tyrant", those two issues being difficult to separate without challenging the entire Russian $\mathrm{XX}^{\text {th }}$ century history.

I will finally argue that a dichotomy tends to be made in non-academic discourse between "the patriotic" and "the liberal" versions of history, displaying antagonistic interpretations of Stalin's role in the war and, as protagonists claim, different attitudes to the Soviet past. As such, those labels and mobilisations around them, both online and offline, are emphasizing the fact that the painful gap that emerged during the Thaw period and exacerbated during perestroika is far from being closed. 
In focusing on those three hypotheses, I devote special attention to the following questions: how is the discussion about the role of Stalin in Second World War developed within online communities, what are the key topics and the opinions at stake? What is the relation between the bottom-up memory and history developed within digital communities and the wider cultural debate, on the one hand, and official narrative and public policies, on the other? How does this debate reflect the tension between the glorious version of the Great Patriotic War and the problematic image of Stalin? How are the members of those communities positioning themselves, how do they perceive and relate to this memory according to the identity they construct, how do they express their engagement in memory shaping? What are the mechanisms of apparition, interaction and establishment of spaces of confrontation over divergent historical interpretations?

\section{Studying Memory in the Digital Age: Methodological Framework}

While memory has always been mediated, nowadays it is no longer limited to lieux de mémoire (Nora 1984) and traditional institutions, but is increasingly shaped by and through everyday internet practices. Indeed, today, instead of going to the library or visiting an archive, we are accessing the past through the web (Historical Controversies Now 2010), where memory and history are from now on collectively constructed through Wikis, networked through digital communities and unlimitedly stocked. Current attempts to find new interpretations of Stalin's role in the Second World War are particularly dynamic on the internet, which offers a relatively free space for non-official, non-academic, personal, and diverse contributions to the collective memory (Garde-Hansen et al. 2009). The social media, by turning upside down the relations between individual and collective memory (Garde-Hansen et al. 2009; Van Dijck 2010; Maj, Riha 2009), is giving rise to new memorial practices, such as online commemorations (De Bruyn 2010), exchanges of personal memories and the treatment of the past through images and multimedia (Hoskins 2011). More specifically, the internet is geared to the construction of heterogeneous interest-based digital communities, including those structured around the - often painful - memories of events from the distant past (De Bruyn 2010, 46; Kaelber 2010), to building spaces of confrontation between opinions, as well as historical milieus and alternative memories, and even counter-histories and countermemories ${ }^{7}$.

7 It is worth mentioning that this role of the Internet leads logically to its instrumentalisation by political power using internet for propaganda purposes. For example, up from the begin- 
This shift makes it necessary to renew the research instruments as applied to grounded sociotechnical digital objects, making connections between online and locality-based realities. The issues raised in current chapter make it necessary to approach social media as a phenomenon based on constant interaction between activities online and offline: today, researchers deal with a social world that contains both traditional and technologically advanced modes of communication and sites of social activity (Postill, Pink 2012). It is evident that the debate on the Great Patriotic War does not exist solely online and is not separated from other aspects of memory discussions, but rather constitutes a part of wider cultural debate, even if the RuNet has been reputed to generate a radicalization of discourse (MacLeod 2009).

For this study I have focused on two cases of conflict debates around two memorial initiatives simultaneously arising in Moscow and Saint-Petersburg, on the occasion of the Victory commemoration in 2010 that provoked a vivid debate concerning the role of Stalin in the Second World War in Russian media, including blogosphere and other social media. The first initiative involved the failed attempt of Moscow City Council to decorate Moscow's streets with placards representing Stalin; the second, successful, launched by the partisans of the reintroduction of Stalin in commemorative space as a reaction to the "Destalinization" programme announced by Federal authorities in 2010, involved a bus travelling around Saint-Petersburg with his effigy on it. My aim was to analyse the most ardent online debates reflecting the Russian bloggers' view of the role of Stalin in the Second World War, on the one hand, and of relevant local and federal memory policies, on the other. To do so, I focused on the blogging and social network platform Livejournal.

While the Russian language blogosphere counts about 85 million blogs, most of the political and social discussion is hosted today on LiveJournal (hereafter referred to as $\mathrm{LJ}$ ), a blogging platform with many social media features (detailed member profiles, "friending", private messaging, and an active commenting culture) (Reuter, Szakonyi 2012; Alexanyan 2013), generating, with its 2.8 million accounts, 90.00o posts daily (Koltsova, Koltsov 2013). Starting from the beginning of the 2000s, a number of authors noted the political and social importance of $\mathrm{LJ}$ debates in the context of the lack of critical debate in tradi-

ning of 2014, 'troll farms' are actively created in Russia as a part of wider informational war strategy. See for example Daisy Sindelar's (2014) article “The Kremlin's Troll Army.” The Atlantic. August, 2014. Accessed February 20, 2018. <http://www.theatlantic.com/international/archive/2014/08/the-kremlins-troll-army/375932>; see as well Aric Toler's research "Inside the Kremlin Troll Army Machine: Templates, Guidelines, and Paid Posts" Global Voices Online, March 14, 2015. Accessed February 20, 2018. <https://globalvoicesonline.org/2015/03/14/ russia-kremlin-troll-army-examples/>. 
tional media in today's Russia (Krasnoboka 2002; Lonkila 2008, 1130; MacLeod 2009,13 ). Qualified 'the discussion centre of the Runet' in 2010 (Etling et al. 2010), LJ still carries, together with Facebook and Twitter, the reputation of Russia's most politicized social network, while "native" Russian social networks such as Vkontakte, Odnoklassniki, MoiKrug and MoiMir remain less politicized. This role was emphasized during the 2011 contested legislative elections, when of the top 25 Russian LJ blogs, 8 were run by opposition activists posting extensively about electoral fraud. Russian most well-known political blogger Alexei Navalny runs Russia's 3rd most popular LJ blog, focusing his attention on corruption scandals and electoral fraud (Kol'tsova, Kol'tsov 2013).

Up from 2012 LiveJournal starts to lose its popularity facing the rapid growth of more "up-to-date" social media as Facebook and Vkontakte (Forbes 2013): from January to August 2011, the monthly number of unique users to LiveJournal worldwide dropped by 8.2 million to 27.7 million (-23 per cent), and of Russian LiveJournal by 2.8 million to 8.6 million ( -25 per cent), according to materials from Comscore (Vedomosti 2011). As for Alexey Navalny who owes his political reputation to $L J$, the leader of Russian liberal opposition diversifies his communication channels by creating standalone $\operatorname{sites}^{8}$ as well as Twitter, Vkontakte and Facebook accounts as a response to $L J^{\prime}$ s popularity drop. According to Maxim Kornev, Assistant professor and lecturer at the Institute of Media Studies of Russian State University for the Humanities, while up from 2013 LiveJournal's role of information diffusion is weakening, its role of "topicstarter" remains almost undamaged: $L J$ is still used by different political forces to organise informational and propaganda attacks, the information being then virally relayed by Twitter, Facebook and Vkontakte ${ }^{9}$.

To explore the discussions and mobilisations around two controversial issues, I have chosen to focus primarily on discourse analysis (including however some visual data). The corpus analysed contained 19 posts and more than 5.500 comments selected within LJ. The study proceeded through two stages. The first consisted of the identification of the debate by looking for the key-words related to the controversial issues, "Stalin's portraits" (portrety stalina) or "Stalin's plackards" (plakaty Stalina), using the web search engine "Yandex Blogi", identifying relevant discussions containing this expression through the chosen period of the debate (February-April 2010). This first selection resulting in 744 posts and comments was followed by manual selection of most popular

$8<$ https://navalny.com/>.

9 Expert interview with Maxim Kornev, author's personal archives. However, it should be pointed out that the present article is based on the research conducted in 2010, when the political and social importance of $L J$, as well as its role in the information diffusion, was on its top. 
discussions (i.e. gathering over 100 comments), eliminating purely informative or marginally relevant posts (reposts of the same newspaper information, for example) and giving priority to the motivated and historically founded reactions of internet users to memory initiatives, namely the posts and comments explaining the reason why this initiative is approved or disapproved. The sample that resulted from the key-word search that I subjected to a qualitative analysis represented 19 posts followed by $5.55^{2}$ comments.

At the same time, since in the Beaulieu's classification the communities observed could be classified as "social phenomena which exist primarily online" (members may have some offline contact but the majority of their contacts and their primary experience of that setting are online, their interactions and contacts are routinely computer mediated) (Beaulieu 2004), I have adopted the method of online ethnography. Since participants in that setting communicate through online behaviour, the approach consists in "being there", that means becoming part of selected communities through a membership, observing discussions and behaviour, watching text and images and establishing direct contact with the social world studied (Garcia Cora et al. 2009, 52), without however making any personal contributions in the debate to keep a researcher's neutrality. For this reason, the second stage of the study implied continuous daily observation of online pro-Stalin network "Stalinobus" emerging in April 2010 as a reaction to those discussions; triggered by the initial debate of Stalin's portraits, the activity of communities' members of the network were cemented for the long term in 2011 and early 2012. It should be noted that in order to "be there", I did not have to create a special profile within those networks for the research purpose, since all the discussions are open to all internet users and can be accessed freely. The long-term observation (from April 2010 to late 2011, then from early 2012 up to 2013) involved discourse and visual elements analysis within the sample of eleven independent but related units, located on different platforms (individual blogs, communities of blogs, SNS communities, standalone blogs, websites), forming together a sort of proStalinist social network.

\section{The Controversy over Stalin's Reintroduction into Commemorative Space}

In February 2010, the Moscow City Council unveiled a project emphasizing Stalin's role in the Great Patriotic War "as the head of the military headquarters, President of the Soviet government, marshal and generalissimo" through posters bearing his effigy on the occasion of the Victory Day. The municipal 
authorities justified this decision by saying that the Mayor's office had merely responded to the initiative of a committee of Moscow Great Patriotic War veterans (Rosbalt, 19.02.2010). Some weeks later, placards and busts of Stalin appeared spontaneously in several towns in Russia, provoking different reactions of local authorities: in Vladivostok, for instance, the Mayor's office authorized for display the image of Stalin in the city to "respond to citizens' requests", whereas in Iakutsk, a city located in the north of Russia, a similar request by the Veterans Committee elicited a formal refusal from the mayor (Rossiiskaia Gazeta 2010.04.20; 2010.04.30). Those attempts to reintroduce Stalin into the commemorative space have triggered heated debates online.

\section{Watchdogs of the Great Patriotic War Memory}

For two months, the unfolding debate in the blogosphere clearly illustrates the societal controversy raised by the place reserved for Stalin in celebrations of the Victory. The analysis of these often stormy discussions shows that, beyond the divergent interpretations of Stalin's personality and his role in the war, typical of the social memory in Russia and therefore locatable in the blogosphere, the posters revealed the equally controversial evaluations of the official memory policies, bringing to light the marked politicization of Stalin's image. In fact, some of the discussants considered that the posters were not an isolated case of local initiative, but part of a broader authorities-led program for the "re-Stalinization" of the Great Patriotic War narrative. According to them, the appearance of Stalin's image as victor in Moscow's streets pertains as much to memory policies as to the general orientation of the regime: the image of the generalissimo was supposed, they contend, to send a strong signal to society, giving it to understand that the current Russian state has, at long last, fully assumed its continuity with the Stalin era and the methods specific to it. "If this regime allows the glorification of Stalin, it is only one step from the Stalinist actions ${ }^{10}$ ", states the blogger 'moullenoir' on April 11 ${ }^{11}$. The commentators, apparently feeling that their views represent a minority in Russian society, deplore the influence of "Soviet mentality" and the population's "slave syndrome", which means that it always has a need for a "great leader": user "bene$n a$, for example, wonders why Stalin is still so appreciated in Russia, in spite of

\footnotetext{
10 All translation from Russian are made by the author of the article

11 'moullenoir' (April 11, 2010), 'Stalinu h*i'/'F*ck Stalin', Livejournal, <http://uskov.livejournal.com/11628g.html?thread=6161473\#t6161473> (accessed February 1, 2014)
} 
the magnitude of repressions ("It's quite enigmatic why in presence of at least one repressed in every family so many people love him ${ }^{12}$ ).

Other discussions focused on the methods to prevent the authorities from exposing portraits. While some users appeal to "minor vandalism" (calling people to tear off the placards or to throw red paint all over them), others proposed to organise a full-scale mobilisation. The issue provokes strong civic sentiments even among usually passive persons: thus a user 'lenkalen', visibly shocked by the decision of City Council, states that "Partisanship is not a method", and that "we need the unity of civic forces, manifestations, collective declarations etc. Due to my laziness, I never participate in any such stuff, but in this very case I am ready to support collective declarations and even to go to manifest $\mathrm{t}^{13}$.

While a part of bloggers was shocked by this reintroduction of Stalin into commemorative space, other commentators hailed the decision of the city council: at last, they claimed, the historical truth would be restored by the reintroduction of Stalin, who had been "unjustly forgotten" within commemorative space in his quality of victor. Disposed to "render Stalin's Victory to him", and wanting to underscore his role in Russia's transformation into a "great world power", they were outraged by the state of forgetfulness into which he had fallen after perestroika, or even, for some, after the 2oth Congress of the CPSU. For a considerable part of bloggers, the portraits of Stalin remain "the symbol of the Victory and the faith of Soviet people of that time", who would "have followed those images to go and to fight". "It's the same kind of symbol as the red star and the arms of USSR. The fact that he was a tyrant is another thing. (...) Nobody can today compare what was more important, the country that survived or the millions of executed ${ }^{14 "}$, states 'Ilya Gorokhov'. He is echoed by another blogger, 'esquirem': stating that even if Stalin was a tyrant, removing this symbol from the Great Patriotic War narrative will weaken the nation: "I don't justify Stalin, on the contrary, I understand that he was a real bastard, but, whatever one might say, he was one of the main factors and symbols of our Victory. And refusing Stalin, we will refuse our main historical achievement. Only a weak nation is capable on that. It's not democracy, it's foolishness ${ }^{15}$.

12 'benena' (April 13, 2010), 'Stalinu h*i'/F*'Fk Stalin', Livejournal, <http://uskov.livejournal. com/116289.html?thread $=6356801 \#$ t6356801 $>($ accessed February 1, 2014) 'lenkalen' (April 12, 2010), 'Stalinu h*i'/'F*ck Stalin', Livejournal, <http://uskov.livejournal. com/116289.html?thread=6192193\#t6192193 $>($ accessed February 1, 2014) Ilya Gorokhov (April 12, 2010), 'Stalinu h*i'//F*ck Stalin', Livejournal, <http://uskov.live journal.com/116289.html?thread=6201409\#t6201409 $>$ (accessed February 1, 2014)

15 'esquirem' (March 4, 2010), 'Prazdnik bez razdora'/'Holiday without discord', Livejournal, $<$ http://vsoloviev.livejournal.com/229779.html?thread=7419027\#t7419027> (accessed Feb- 
The contradiction between two symbols is emphasized by the blogger 'be_it $s o$ ': for him, there is a great "dissonance from the fact that our country has accomplished this great achievement being led by a leader like Stalin". However, for him, the Russian society is not yet ready to raise "such questions", because raising them would mean "stir the boat during the storm": "We have not yet assimilated the system of notions wherein we can adequately relate Stalin to the saint symbol of the Victory ${ }^{16 "}$.

Typically, bloggers had difficulties interpreting this decision of local authorities as a part of wider state policies: rather, comments were pointing out the general confusion of political elites concerning their attitude to Stalin. In particular, bloggers emphasized the dissonance between the official rhetoric and politics: as the blogger 'uskov' puts it, "Judging by numerous declarations of Putin and Medvedev, and heads of United Russia, the power is against the rehabilitation of Stalin and exposing his placards in Moscow streets ${ }^{17}$ ". Other bloggers also point out the inconsistency of public discourse and policies: ' $m r_{-}$ alexandrew', for example, highlights that some months ago "the President has publicly condemned (...) the politics of Stalin". In all evidence, the blogger refers to Dmitrii Medvedev's discourse published in his video blog on the occasion of the Day of Memory of Victims of Political Repressions on October 30, 2009. Entitled "The Memory of National Tragedies is as Sacred, as the Memory of Victories", the discourse firmly condemned Stalin's repressions, Medvedev stating, "the crimes of Stalin can't belittle the feats of people who won the Victory into the Great Patriotic War", indicating Kremlin's position on the issue (Kremlin.ru, 30.10.2009). "Do we have a disorder and vacillation in the ranks of one party? No agreement on this question?18", wonders 'mr_alexandrew', echoed by other confused bloggers.

Faced with the prospect of Stalin's reintroduction into the commemorative space, the NGO Memorial, which has fought for the memory of victims of Stalinist dictatorship since 1986, and the liberal political party Iabloko mobilized against the project, warning the officials of the consequences of such a decision. Iabloko's representatives, for instance, declared that, together with

ruary 1,2014$)$.

16 'be_it_so' (March 12, 2010), 'Tipa tolko voprosy'/'Sort of just questions', Livejournal, < http:// leonid-b.livejournal.com/667464.html?thread=13875272\#t13875272> (accessed February 1, 2014).

'uskov' (April 12, 2010), 'Stalinu h*i'/'F*ck Stalin', Livejournal, <http://uskov.livejournal. com/116289.html?thread=6265153\#t6265153> (accessed February 1, 2014)

'mr_alexandrew' (March 5, 2010), 'Luzhkov i Stalin'/'Luzhkov and Stalin', Livejournal, <http://ru-antidogma.livejournal.com/716617.html?thread=20441417\#t20441417> (accessed February 1, 2014). 
Memorial, they will organize a counter-commemoration, exposing the portraits of Red Army officials arrested, tortured and executed on Stalin's orders just before the War. This initiative has been variously evaluated by bloggers. While "antistalinist" bloggers hailed Iabloko's initiative, for bloggers in favour of the idea of placards, the negative reaction from those that they qualify as a "handful of marginals" is explained by the fact that the Russian population has long been a victim of brainwashing to make them forget Stalin and his "major achievements". After City Council rejected the project under pressure from liberal civil society, but also after a disapproval expressed by some leaders of United Russia, such as Boris Gryzlov, who stated clearly that "for us victor is not Stalin, but people" (Baltinfo.ru, 2010.18.02), these same bloggers accused the municipal authority of going against the "true will of the people", for whom Stalin would always be the symbol par excellence of the victory. The stance of these bloggers is particularly interesting: rejecting out of hand the very possibility of expressing oneself sincerely against the project, they attribute negative societal reactions either to the population's having been "brainwashed" and the influence of NGO's, or to various sorts of manipulation (falsifying surveys); moreover, they manifest in their discourse a strong anti-liberal and antiwestern dimension - according to them, the Russian population has been infected by perceptions of Stalin as a tyrant by the west and its "agents".

The clear divergence of evaluation of the state's memory politics indicates the absence of clarity and coherence in the state's stance on the Stalinist heritage: while some commentators have deplored the "re-Stalinization" of Russia, others have complained of the domination of memory politics by the "liberal pest".

\section{Debate over Stalin's Role in the War Online}

The discussion over the memory politics of the Russian state and on the possibility of placarding the capital with an image of Stalin for the day of the commemoration unfolded against the background of general debate about Stalin's role in the war. Here again, opinions have been divided between two camps: while, for some, the Russian people won the war in spite of Stalin, paying for his extremely grave errors with their blood, for others the war was won thanks to Stalin, since he was the one who ensured good leadership and galvanized the nation. Based on the arguments most often used in this type of discussion, I have tried here to construct a model of the "typical online debate" on Stalin's 
role in the Victory, presenting the opinions of his "adversaries" as well as those of his "defenders" 19 ".

Several types of argument can be highlighted. The historical arguments focus on Stalin's contribution to the Victory, both as Head of the Army and as Supreme Leader of the UsSR. Stalin's "adversaries" most often refer to the high number of the war's victims, which could have been avoided. Figures and statistics are called upon to demonstrate Stalin's mediocrity and incompetence in his capacity as Head of the Army. Referring to him as the "the moustached one", "the vampire", or in an ironic way as the "great leader", the bloggers elicit his inability to draw conclusions from information supplied on the exact dates of the German attack, his strategic errors, the repressions carried out in the Red Army a few years before the war, and so on. "Is it not thanks to the "wise" leadership of the moustached one that the Germans progressed as far as Moscow? And the 26 millions of lives of my compatriots - isn't that cost a bit too high for the so-called "genius"?20', asks rhetorically 'palych_ru'. "The moustached one wiped out the officers (...), he missed all the information about the launch of the attack and subjected the army to the first violent strikes of the enemy'1", affirms 'mahabon'. Other users defend the thesis that the war was won by "Stalin's victims": "It was not Stalin who won the war. His victims did (...). And there would have been fewer victims if he didn't exterminate Army headquarters at the end of the 1930s....2". "The Army won the war, the rear echelon, the Russian winter and smart military commanders. Alexander I of Russia also won the war, but he didn't need to exterminate millions of compatriots for this ${ }^{23}$ ", affirms blogger 'desdichadov'.

19 We should note that « adversaries» and « defenders» of Stalin exist only as ideal-types and models, the reality is, of course, much more nuanced. I am fully aware of the evident disadvantages that this approach implies: indeed, an undiluted sample of 'pro' and 'anti' communities is difficult to obtain, since a part of the debate advocate a much more complicated view on the Soviet epoch and a purely 'positive' or 'negative' vision is quite rare even within radicalised online discourses. Thus the distinction 'pro'/'anti' does not need to be taken as a rigorous border between two isolated types of communities, but rather as a methodological assumption in order to facilitate the data collection and interpretation. 'palych_ru' (February 18, 2010), 'Leonid Gozman o Staline'/'Leonid Gozman on Stalin', Livejournal, <http://ru-politics.livejournal.com/28052206.html> (accessed March 10 2012). 'mahabon' (March 6, 2010), 'Provokatsiya Luzhkova - plakati Stalina v Moskve'/'Luzhkov's Provocation - Stalin's Posters in Moscow', Livejournal, <http://ru-politics.livejournal. com/28423494.html> (accessed March 10, 2012). 'panstudia' (April 12, 2010), 'Stalinu h*i'//F*ck Stalin', Livejournal, <http://uskov.livejournal. com/116289.html?thread=6222401\#t6222401 $>$ (accessed February 12014$)$.

23 'desdichadov' (March 4, 2010), 'Prazdnik bez razdora'/'Holiday without discord', Livejournal, <http://vsoloviev.livejournal.com/229779>.html?thread=7431315\#t7431315 (accessed February 1, 2014). 
Stalin's "defenders" marshal counter-arguments designed to point up his military competences: according to them, Stalin was if not a great strategist, then at least a good organizer, having himself chosen the generals who secured the Victory. As a matter of fact, the bloggers ask, "if Stalin was so stupid and so cowardly", and his generals were "all no-hopers", how did the army manage to win? "Who made the decisions thanks to which we found ourselves in Berlin? ${ }^{24}$. Parallels with other countries are mobilised in order to legitimatize the reintroduction of Stalin into the commemorative space. For some bloggers, Stalin has a right to be remembered in the same way as Churchill and Roosevelt are remembered in England and the United States respectively: after all, all three of them were commanders-in-chief of victorious countries: "Why can Churchill and Roosevelt can be symbols of England and the United States, but Stalin can't be the symbol of Russia? ${ }^{25 " .}$

Statistics showing the USSR's progress in heavy industry are often put forward to emphasize the "objective role" played by Stalin in the modernization of the country. According to this type of argumentation, the Victory would not have been possible without Stalin, since it was he who had set the country on the path of modernization, enabling it to reach an industrial and military level sufficient to conduct and win the war. If no modernization had been carried out, the Russian nation would have been destroyed, as was foreseen by the "Barbarossa" 26 military plan: thus, it was thanks to Stalin, these bloggers maintain, that they are alive today. The Molotov-Ribbentrop pact made it possible to postpone war, leaving the country more time and possibilities to mobilize.

Faced with the exultation of Stalin's industrial achievements, his "adversaries" raise ethical arguments, underscoring the immorality of glorifying tyrants, notwithstanding their "objective achievements" (i.e., material progress) in different domain. Highlighted is the complicity and collaboration between Hitler and Stalin, leading to the splitting of Europe in accordance with the secret protocols of the Molotov-Ribbentrop pact: for these bloggers, there was no difference between these two tyrants.

\footnotetext{
24 'm_b_polyakov' (February 18, 2010), 'Leonid Gozman o Staline'/'Leonid Gozman on Stalin', Livejournal, <http://ru-politics.livejournal.com/28052206.html> (accessed March 10, 2012).

25 'kudrjashovai' (March 4, 2010), 'Prazdnik bez razdora'/'Holiday without discord', Livejournal, <http://vsoloviev.livejournal.com/229779.html?thread=7452307\#t7452307> (accessed February 1, 2014).

26 See more on the development of the ideological bases of operation "Barbarossa": André Mineau (2004), Operation Barbarossa. Ideology and Ethics Against Human Dignity. Amsterdam: Rodopi.
} 
Often, family war memories that have been handed down the generations are mobilised to counter the "Stalinist" narrative: grandparents' testimonies are called upon to legitimate the viewpoint of the speaker. "You know, my grand-dad is a veteran. He was through all the war. And I have never heard from him the desire to look at the portraits of Stalin", states user 'ptitsa'. In another thread, user 'tushinets' appeals to memories of his two grandfathers: "As both of my grandfathers told me, nobody ever yelled "For Stalin!" during the attack". User 'voskresenskii' echoes this opinion by stating that seeing the portraits of Stalin will be tough for his 93 years-old grandmother and his two deceased grandfathers, "but also their 10 brothers and sisters, which had all been through the entire war. And some of them were afterwards sent to camps because they were partisans ${ }^{27 "}$.

For those bloggers, the question of Stalin is above all one of leadership methods: can one leave morality aside and justify the mass repressions by the "positive" aspects of the regime, be it the industrialization of the country that enabled the Victory in this most horrible of wars? Bloggers often raise the example of Germany, where the memory work that has been carried out no longer permits one to claim that Nazism had its "good sides". Another controversial aspect in the debate is the key argument of Stalin's "defenders", who claim that as the soldiers launched their attack they cried out "For Stalin", thus proving the essential role of the Leader in the Victory. For Stalin's "adversaries", this is only a myth created by Soviet propaganda after the war in a bid to shore up the totalitarian regime. In their view, people fought not for the Party, and still less for Stalin, but instead for Holy Mother Russia, and for their own families who, even behind the front line, were threatened both by Hitler's troops and by Stalin's reprisals ${ }^{28}$ : from this viewpoint, the war was, indeed, a "people's" war

27 'ptitsa_fenix' (April 13, 2010), 'Stalinu h*i'//F*ck Stalin', Livejournal, <http://uskov.livejournal.com/116289.html?thread=6340161\#t6340161;'tushinets'> (March 6, 2010), 'Provokatsiya Luzhkova - plakati Stalina v Moskve'/'Luzhkov's Provocation - Stalin's Posters in Moscow', Livejournal, <http://ru-politics.livejournal.com/28423494.html?thread $=405188934 \# \mathrm{t}$ 405188934;'voskresenskii'> (March 5, 2010), 'Luzhkov i Stalin'/'Luzhkov and Stalin', Livejournal, <http://ru-antidogma.livejournal.com/716617.html?thread=20441417\#t20441417> (accessed February 1, 2014)

28 According to the legislation then in force, encircled officers could be judged for "abandoning their positions with a view to facilitate the enemy advance" (Art. 193 paragraph 21 of the Penal Code of the USSR); officers that had become prisoners could be judged for "abandoning the military unit" (Art. 193, paragraph 7), "fleeing from the enemy" (paragraph 8 ) or "capture unjustified by the military situation" (paragraph 22). Thus, the very fact of being made a prisoner was considered a crime, following the example of acts of betrayal. Penal responsibility of "family members of traitors to the fatherland" could be evoked, in which case they were sentenced in absentia (Polian 2002, 124). 
('narodnaia voina'). Underscoring the fear that reigned in the army due to the policy of banning all retreat from the battlefield without orders, they maintain that the soldiers had no other choice but to fight.

Analyzing the blogosphere debate makes it possible to get a measure of existing societal controversies over the role reserved for Stalin in the national holiday: initiatives by citizen groups to promote his image as a symbol of the Victory quickly came up against counter-reactions on the internet, leading to the construction of spaces of different opinions. I should note that the discrepancy expressed in the blogosphere is a part of a wider cultural discourse, where the debates on Stalin's role in the war are often articulated in terms of opposition of moral arguments and arguments about efficiency of the State machine (Bomsford, Bordugov, 2006). The question "Who won the war, the people or Stalin" persists in the media discourse as well and remerges regularly on different occasions ${ }^{29}, 30,31$.

But in 2010, the internet not only became a battle-ground for the internet users who wanted to express something on the subject: it became a means to organize and create a sustainable offline social mobilization aiming not only to reintroduce Stalin into the commemorative space in his role of a victor, but also to promote a lasting patriotic view of Soviet history by opposing it to what is considered to be a "dominant discourse". In order to illustrate the birth and evolution of a mobilization of this type, I will look at the case-study of a movement initiated by bloggers, "The Victory Bus", or "the Stalinobus".

\section{Mobilizations around "the Victory Bus": New Form of Memory Activism, Old Discrepancies}

The history of the "Stalinobus" began in April 2010, as a reaction to the debate around placards. Disapproving of the decision of City Council to renounce the project, a blogger called Viktor Loginov, a 28-year-old resident of Saint-Petersburg, stated that civil society will "restore the historical truth of the Great Patriotic War" on its own. He organized a money collection on his blog for a bus to carry an effigy of Stalin through the city with the slogan "Eternal Glory to the Victors!" ('Podarok k 9 maia' 2010). His Livejournal post titled "A present for May 9 ", aroused great enthusiasm among bloggers deceived by the failure of the project, who found the idea tremendous: the required amount of 17 thousand

29 Ekho Moskvy, May 8, 2010.

$30 \quad$ Komsomol'skaia Pravda, May 8, 2010.

$31 \quad$ Novaia Gazeta, November 12, 2012. 
Roubles ( 425 Euros) was quickly collected and, despite the absence of authorization by the municipal authorities, a contract with a private transport company was signed to have the bus running in the city starting from May 7.

As with the case of the effigy of Stalin, the blogosphere served us as an observation field of the campaigns underway. When news of the "Stalinobus" spread throughout the blogosphere, internet users against the idea of seeing Stalin in the streets of Saint-Petersburg declared "a fight against the image of the tyrant". One popular blogger, Andrei Malgin ('avmalgin', 13,864 readers), published on his blog of 17 April detailed instructions for making homemade "bombs" representing an empty light bulb filled with red paint, a symbol of the blood spilt by the Russian people: in the text titled "let's welcome the Great General with dignity", he proposed to his readers to throw these "bombs" at the images of Stalin adorning buses. This publication generated 298 commentaries: while a minority of bloggers called for people to "reconcile with their history and to stop this brawl over the Victory", the majority were radically split. Some radical bloggers proposed "quite simply to burn the buses", while for other commentators, throwers of bombs and destroyers of posters were "doing the work of Nazis" and "vilifying the history of Russia". The result of the bloggers mobilization was the continual desecration of the bus: at the end of the first day's travel, the face of Stalin was completely sullied by paint. Responsibility for this act, qualified by the organizers of the advert as "vandalism", was claimed by the St. Petersburg department of the liberal political party Iabloko. Simultaneously, the struggle continued on the internet, mainly using images: "defenders" of Stalin thus drew and published a caricature representing Hitler thanking key figures of the Russian liberal opposition ("Thanks! Thanks, my dearest ones!") for their efforts against Stalin's image (Figure 6.1).

\section{Patriotic Mobilization Online: Crowdfunding for the Generalissimo}

While the efforts of liberal parts of society, as a response to this concrete initiative, were only short term, the pro-Stalin movement, emboldened by its initial success, became sustainable and unveiled a broad programme to re-evaluate the image of Stalin and the whole of the Soviet history. In fact, far from being an isolated act in the months of April and May 2010, "Stalinobus" movement rapidly took on a considerable scope, building up its social capital through a mobilization of enthusiastically "patriotic" internet users. This spontaneous movement formed very quickly around the organization committee: apart from the pioneer and the author of the idea of "Stalinobus" Viktor Loginov (LJ 'viklamist'), members of the committee included Dmitrii Lyskov (LJ '_lord_'), a 


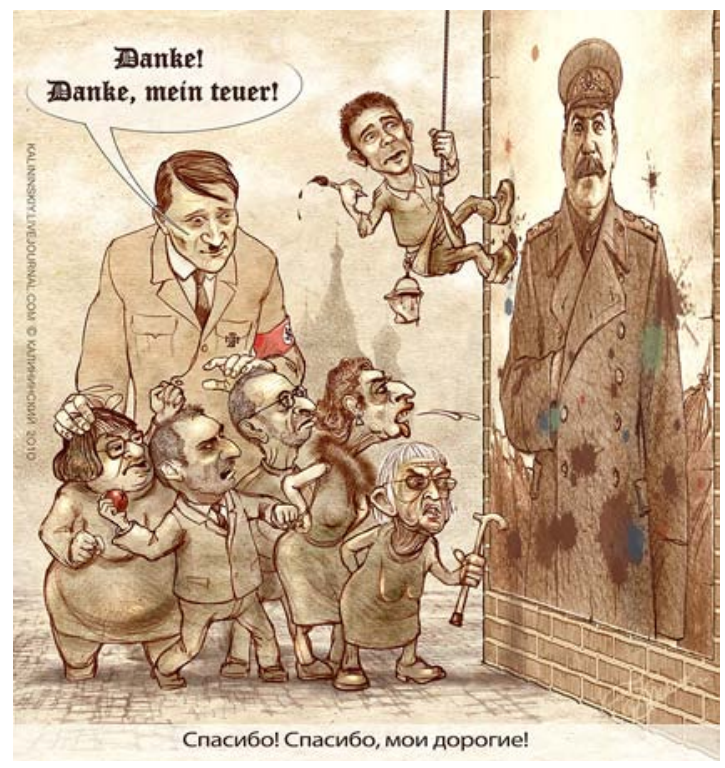

FIGURE 6.1

Caricature drawn by the blogger

"kalininsky". Among the

"spitters", one can see, for example, human rights defenders Valeria Novodvorskaia and Ludmila Alekseeva, President of "Holocaust" foundation Alla Gerber, chess champion and opposition politician Garry Kasparov, liberal journalist Nikolai Svanidze and opposition politician Ilia Iashin. Note the grammatically incorrect German in the caricature. Source: <http://kalininskiy.livejournal. com/188521.html $>$, accessed 28 February, 2018.

32-years old journalist and historian belonging to a "patriotic" wing of Russian historiography ${ }^{32}$, and also Andrey Martianov (LJ 'gunter_spb'), an impassioned writer and translator of the history of the Second World War who characterizes his political opinions as "deeply anti-liberal", as well as other popular bloggers who often had several hundreds of permanent readers. ${ }^{33}$ The movement fast established itself on the main social networks: "Stalinobus" communities were created on Facebook ${ }^{34}$, Vkontakte ${ }^{35}$, and Twitter ${ }^{36}$; the movement procured itself three identical sites, including one in the Russian national domain (.pф/ rf, 'Russian Federation') and another in the domain of the Soviet Union (.su,

32 Dmitrii Lyskov has written several books on the question of Stalin's repressions: "Stalinskie "repressii". Velikaia lozh' dvadtsatogo veka"/"Stalin's "repressions". The greatest lie of twentieth century" (2009), "1937. Glavnii mif xx veka"/ "1937. The main myth of the 2oth century' (2010).

$<$ http://los-desdichados.livejournal.com/profile>, <http://periskop.livejournal.com/profile $>$, <http://rene-spb.livejournal.com/profile>, <http://sotnik.livejournal.com/profile> etc. Accessed February 20, 2018.

34 <https://www.facebook.com/stalinobus>, accessed February 20, 2018.

35 Vkontakte [In Contact] is the most popular free Russian social media site and boasts more than 100 million active users and a daily audience of more than 25 million users $<$ http://vk.com/stalinobus $>$, accessed February 20, 2018.

$36<$ http://twitter.com/\#!/stalinobus >, accessed February 20, 2018. 
'Soviet Union') ${ }^{37}$; a blogger community called "The Commissariat of the People for Historical Truth"38 gathered more than six hundred blogger-partisans for the movement. ${ }^{39}$ The name of community is not incidental: it shows the engagement of the bloggers to restore "historical truth" by revalorising the role of Stalin in the Great Patriotic War.

The functioning of digital communities networks rallying under the banner of "Stalinobus" is governed by several principles. First of all, they display an openness towards initiatives coming from below, and from all corners of Russia: all of the network's communities display a set of "do-it-yourself" style instructions titled "How to organize a campaign in my town". The organization committee is also open to questions from internet users who would like the bus to do runs through their towns. Next comes the principle of crowdfunding, transparency and mutual financial aid: money collections organized by the bloggers operate via an online payment system "Yandex Money", and screenshots of the account are regularly published so that every internet user can monitor the transactions; it is worth noting that the same transparent system was used in 2012 by opposition blogger Alexey Navalny to finance his municipal campaign. Excesses of collected money are redistributed by the organization committee among towns where the collected sums are insufficient to enable the project's implementation. Lastly, the organization stresses in particular its complete independence from political movements and the state: in a press release dated February 2011, it emphasized the independent and private character of the initiative, which aimed to "celebrate (...) the 66th anniversary of the Great Victory (...) not only under the auspices of the official commemoration, but personally, that is, as a group of Russian citizens, independent of parties and political organizations" ('Avtobus Pobedy poiavitsia', 2011.02.28).

Since the first initiative of May 2010, the movement has continued to rally greater numbers of Internet users under the "Stalinobus" banner: while in 2010 the bus only ran in Saint-Petersburg, in 2011 the list of cities was extended to Moscow, Omsk, Kirov, Volgograd, Ufa, Novosibirsk, Sebastopol, and Irkutsk ('Aktsiia "Avtobus Pobedy" 2011), thus assuming a genuinely national dimension. At the present time, the movement claims, in geographical terms, to embrace the entire Federation "from Kaliningrad to the Urals" and "from the Urals to the Kurile Islands", and is endowed with local self-designated coordinators.

37 <http://сталинобус.pф/>, <http://stalinobus.info/>, <http://stalinobus.su/>, accessed February 20, 2018.

38 'Narodnii Komissariat Istoricheskoi Dostovernosti'. The name of the community revisits Soviet abbreviations, such as, for example, the NKVD: the People's Commissariat for Internal Affairs, etc. <http://ru_nkid.livejournal.com/>, accessed February 20, 2018. 


\section{Civic Memory Action as a Response to the "De-Stalinization Programme"}

Far from being a mere accident, the movement's success must instead be considered part of a more general tendency to re-evaluate the whole of the Soviet history through some key events and historical figures, the radical manifestations of which are articulated in the space of public memory (Etkind 2009; Dubin 2009, 2011). For better or for worse, the Russian authorities have tried since 2008 to develop a "useable" past and promote, intermittently, a discourse condemning Stalin and Stalinism (Sherlock 2011: 93). One can mention in this connection the "Destalinization Commission" formed in 2011 on a basis of the program "On perpetuation of memory of victims of the totalitarian regime", prepared by the Working Group on Historical Memory of the Presidential Council for Civil Society Development and Human Rights. Some State-financed blockbusters, as Nikita Mikhalkov's "Burnt by the Sun - 2" film (2011) devoted to the Great Patriotic War subject, also promoted negative representations of Stalin's role in the war. Also, Russian political authorities regularly criticise Stalin's legacy, as for example Dmitrii Medvedev's, expressing in his public statements his negative attitude to this historical personage: thus, for Russian Prime Minister, Stalin "was in war against his own people" (Dmitrii Medvedev Facebook, 2012).

Even if government's attempts in "destalinization" direction remained quite limited and public statements ambiguous, the "patriotic circles" of Runet have not remained static in the face of these developments. An analysis of the materials published on the movement's various relays (sites, blogs, social networks) reveals its motto: in contemporary Russia, history and memory are fields of struggle in which "just" interpretations, that is to say "patriotic" ones, are opposed to the falsifying discourse, belittling national history by reducing Stalin's role in the Victory to silence and denying his historical merits. In fact, the movement is positioned as "civic resistance to revisionism and to the reevaluation of the results of the Second World War and the Great Patriotic War, and to so-called de-Sovietization/de-Stalinization ("Commissariat of the People for Truth") and as "an educational project" ('Pochemu ia podderzhivaiu' 2010.03.19). In this way, the dissemination and preservation of the myth of the "Great Stalin" has taken the appearance of a critical re-evaluation of Soviet history. According to the members of the movement, ever since the collapse of the Soviet Union, Soviet history has been a victim of a real campaign to discredit and defame it, undertaken by "anti-Soviet and anti-Russian forces", which aim in particular at the Victory, the symbol of Russian national pride, by attacking the image of Stalin - inseparable from it. Following this logic, 
blackening Stalin means blackening Victory. One widespread opinion, according to which the Victory was won by the people in spite of Stalin, is considered a logical consequence of this "information war". The aim of this campaign is allegedly to cultivate shame in the Russian people and promote a "complex of collective guilt" for the entire seventy years of Soviet history, presenting the period as "an inexplicable aberration, a chain of catastrophes and of monstrous crimes" ('Pochemu ia podderzhivaiu' 2010.03.19); they aim to undermine "the international authority of the Great Russia" and to "shape in our fellow citizens a negative attitude toward the history of their country" ('Avtobus Pobedy 9 Maia' 2012).

It is exactly this discourse against which participants oppose their version of "accurate" Soviet history: beyond Stalin's reintroduction into the commemorative space as a victor, the point is to rehabilitate and purify Soviet history from being "smeared". Based on various declarations made by the movement, it is easy to see that this rehabilitation consists in foregrounding the memory of a glorious history of the war to the detriment of a darker one: for example, discussing the issue of Russian society having to fulfill a duty of memory, the organizers speak of "all the defenders of the Fatherland who, in the hard years of the Great Patriotic War fought and worked for Victory with the name of Joseph Stalin on their lips and under [Stalin's] leadership" ('Avtobus Pobedy 9 Maia' 2012); on the other hand, nothing is said about the memory of the victims of Stalin and of his policies; these pages of history do not seem to concern the movement, but are instead considered "calumnies" and "smear attempts."

The ambition to promote a patriotic and in fact very selective view of Stalin's role in the war is highlighted by the movement's reactions to certain state initiatives in the domain of history and memory. In February 2011, a "programme of national reconciliation and of immortalization of the memories of victims of totalitarian regime" was adopted by the Russian authorities. Elaborated by the Development Committee for Civil Society and Human Rights in close collaboration with Memorial, the programme set out to achieve a number of measures in the domain of history and memory in order to get beyond the totalitarian heritage of present-day Russia (opening of archives from the Second World War, compensation for victims of Stalinist terror, creation of bipartite commissions from Russia and the Baltic countries on the most complex issues in common history, etc.). Baptized in current language the "Programme for the de-Stalinization of Russia", it gave the social debate on Stalin and Stalinism a second wind. The "Stalinobus" organizers quickly took a stance. In a press release from February 2011, they violently criticised current policies on history and memory. According to them, "de-Stalinization" represents a danger for national memory: "The change of context obliges us to say that the state, 
though it declares an absence of a dominant ideology, is in the process of trying to impose a univocal view of history, to infect citizens with the idea that the entire Soviet period was but a black stain on Russian history. From the negation of Stalin's role in the Victory it is but a step to the negation of a whole set of achievements of the Soviet state (...) and to the negation of the Great Victory", affirms the press release ('Press-reliz Aktsii', 2011)

The author of the call affirmed that, faced with the project of "de-Stalinization", the movement would double its efforts to prevent the "vilifying of national history". The recurrent theme of civic resistance to a "falsified" history imposed from above enabled "Stalinobus" to appear as a space of patriotic counter-history and counter-memory, one developed on the internet thanks to the mobilization potential that it offers. In fact, less than two years after it emerged, the project extended beyond the Russian borders thanks to the growing activism of internet users: hence, on 10 April 2012, one month before the commemoration of the 67th anniversary of the Victory, 30 Russian, and 3 Ukrainian towns confirmed their participation in the project; 137420 Roubles, or almost 3500 Euros were collected by Internet activists to make it possible to expand the network of circulation to ensure that "our voice and our protest is heard from Vladivostok to Kaliningrad" ('Avtobus Pobedy. Promezhutochnye Rezul'taty', 2012). In addition, the organizers announced "the confirmation of activists from the Baltic countries": the aim was to have the "Stalinobus" travel to Riga and Tallinn. Even if the organizers came up against considerable resistance from the municipal authorities in both these capitals, they did not renounce their provocative approach, though they were fully aware of the possible consequences, including the clash of differing national versions of the Second World War or an umpteenth "memory war" further poisoning the already strained relations between Russia and the Baltic countries. In 2013, the organizers continued their actions, this time, supported by the Communist Party and some trade unions; however, the buses still circulated on crowdfunding principle: in 2013, the Stalinobus action named "Give the Victory her name back!" ('Stalinobus 2013', 2013) was mainly sponsored by individual contributions. Besides, the organization widened its scope of action, campaigning for other measures to strengthen the link between Stalin and Victory, for example, renaming Volgograd back into Stalingrad ('Makety dlia aktsii', 2013).

The project's success continues to attract internet activists, sometimes very young ones, to the "just cause": for example, the coordinator of "Stalinobus" in Ufa, the capital of Bashkiria, was only born in $1986 .{ }^{40}$ This same success, however, provokes, starting from 2011, fierce reactions from representatives of

$40 \quad$ Eldar Latypov-Shi. <http://www.latypov-shi.livejournal.com>, accessed February 20, 2018. 
liberal political parties, defenders of Human Rights and some State officials: in April 28th 2011, the President of the Development Committee for Civil Society and Human Rights and one of the authors of "Destalinization program" Mikhail Fedotov complained to the Federal Antimonopoly Service about the Stalinobus project, on the grounds that placing Stalin's portraits on buses is "provocative" and violates the law on advertising. Another member of "Destalinization committee", Sergei Krivenko, promised to inform heads of regions about the action, emphasising the fact that the "Destalinization" programme was initiated by President Medvedev and carried out by President Putin. The leader of the political party "Iabloko" Sergei Mitrokhin states that, just as before, members and activists of his party would paint over Stalin's image with red paint. For him, "State authorities must show greater firmness [on this issue]. (...) Perhaps the war would never take place, should it not be for the idiotic Stalin's politics and his cronyism with Hitler" (Izvestia, 31.01.2013)

Notwithstanding the resistance, the authors of the project display ambition and optimism about the future, maintaining not only their determination to continue to expand the movement "based on the internet community (my italics, - EM) and with the help of interested citizens", but also to seek out other forms of struggle in the "information war", including: publishing brochures, launching a journal, strengthening the work on the internet etc. The organizers announced at the start of 2012 that at the current moment "the point is to create a legally recognized NGO" ("Commissariat of the People").

While this spectacular development in 2010 and 2011 seemed to forecast not only the growth of the movement's popularity on the internet and the possible emergence of imitators, but also its eruption in the field of memorial NGOs, with the inevitable restructuring of the institutional memorial landscape and an important turn in Russian collective memory, the Stalinobus movement started to falter as a civic historical initiative up from 2013. The decrease of activists' interest to the project was due to its recuperation by neoliberal patriotic political forces. Thus in 2013, the Stalinobus organisation process was split, the similar action was organised by the activists of the movement "Essence of Time" 41 ("Sut' Vremeni"), an avatar of classic Russian intelligentsia discussion club with a strong neo-Soviet patriotic bias. Its eminent leader, Sergei Kurginian, bears a neo-conservative antiliberal ideology. This self-styled academic has become in 2010 a $\mathrm{TV}$ commentator and was purposefully promoted on governmental television via The Historical Process Tv Show. During this show, Kurginyan defended Stalin's legacy and, globally, the UsSR period as the period of power and glory. He also played an eminent role during the 2011 anti-Putin 
protests, organising counter-manifestations against liberal opposition. It pays to note that the official LiveJournal Stalinobus project community claimed 'a temporary hold-on" of their activities because of "lack of capacities to influence the media environment'. Thus, the Stalinobus collective encouraged all the imitators to carry on the project on their own: the project started to live its own live as an independent concept. However, the official community announced that their struggle for the Russian history will continue: other forms of action were to be elaborated (Press-Reliz, 24 April 2013).

Today, the activity of the original Stalinobus community was reoriented to crowdfunding money to support "Novorossiia", term designing a confederation of self-proclaimed separatist pro-Russian Ukrainian republics. The root LJ community as well as Facebook and Vkontakte branches have adopted the State-promoted imperial patriotic rhetoric, linking current situating in Ukraine to the overall historical context of the Great and Mighty Russian Empire. Not only this development emphasizes the proximity of Stalinist ideology and modern Russian patriotism rooted into the glorious imperial past; it also shows that "memory watchdogs" are in fact the social basis of new imperial patriotic discourse. From their point of view, the historical justice is about to be finally accomplished.

\section{Conclusion}

In this chapter I have argued several points. First, that the debate on Stalin's role in the Great Patriotic War (and in Russian history in general) is far from being closed: the confrontation between conflicting interpretations has given rise to multiple debates in public space, which become particularly ardent as commemorative occasions near. The missing memory work, repressed trauma, and the absence of a defined and coherent memory policy with regard to the Stalinist heritage constitute the main obstacles to homogenizing collective memory. A study of the debates and mobilizations in the blogosphere confirms that the young urban elite is as split on the issue of Stalin and Stalinism as the Russian society as a whole: Russia is still haunted by its "unburied past" (Etkind, 2009:182).

Second, while tendencies to re-evaluate the Soviet history emerge and are articulated in public space, internet plays an increasingly important role in mobilizations bearing on history and memory. Abolishing the borders between profane and scientific discourse, between producers and consumers of historical knowledge, internet fosters the greatest plurality of interpretations, whose influence rests not on historical veracity but instead on the authors' ability to 
make themselves heard in the vast sea of the Internet. While the emergency of "memory watchdogs" primarily online can be observed, the openness of the internet facilitates the permanent clash of interpretations of the role of Stalin in the Second World War. Those spaces of alternative memory are, in the present Russian context, part of a logic of struggle for the "true" memory of the Great Patriotic War, as opposed to the "falsified" one. The return of the "Great Leader" in his capacity of victor of the Great Patriotic War is presented as a critical and necessary re-evaluation of the Soviet history in the context of the state's inability to carry out a coherent memory politics. ${ }^{42}$ The State's attempt to "destalinize" Russian history accentuated memory activism that struggles for the return to the glorious version of the Great Patriotic War. This activism emphasizes the fact that through its ability to foster debate and form groups of opinion, the internet is becoming, and increasingly so, a milieu in which the spaces of patriotic counter-history and counter-memory are created in opposition to the officially promoted discourse.

Third, supporters of the "patriotic" view of history who adopt the appearance of a "critical re-evaluation of history" are gaining more and more digital ground. They are the most active, higher mobilized than liberal civil society, and web-savvy. The resulting mobilizations may turn out to be either short or long term, depending upon the goals pursued; once launched by internet users, they are liable to leave the bounds of the internet ${ }^{43}$ and enter the field of offline civic action. The success of the "Stalinobus" initiative only confirm the mobilizing potential of the "struggle for patriotic history". In the context of the state's inability to establish a coherent memory policy for re-thinking historical Stalinism, the digital communities emerged from below can be considered the avant-garde of the global movement of patriotic re-evaluation of the Soviet history. The marked success of the pro-Stalin movement within commemorative space demonstrates its mobilizing potential, revealing the need, being expressed by sections of society via "patriotic" communities, for an alternative reading of the Soviet history. In plus, the latest developments in connection with the Ukrainian crisis indicate that this particular "patriotic" vision of the Soviet history often goes hand in hand with a certain neo-imperial way of thinking and receptiveness to State-promoted patriotic ideology.

42 For more about the ambiguities in the memory politics of the Russian state see the chapter by Malinova and the chapter by Sniegon in this volume.

43 The term "internet bounds" can be applied with good reason to the Russian context, where the situation of "digital divide", i.e. the inequality between those who have access to internet and those who don't is quite sharp: indeed, according to the 2012 statistics, only half of the population is connected (Lenta.ru, June 2, 2012) 
The retrospective view in 2018 on the findings of this study conducted in 2010-2011 allows to confirm and nuance them. While Livejournal have lost digital ground and hence its influence in shaping the debate around controversial historical figures, Livejournal's "old guard" (influencers with huge number of followers keeping their journal active despite the diminishing role of the platform) continue to harvest hundreds of comments by solely posting a few lines about Stalin ("I don't understand how we can still have people respecting this old moustached Georgian and his deeds", as Livejournal influencer "tema" put it in January 2018, instigating a 768-comments worth debate). In parallel, the debate is full swing on more recent social media (eg. Facebook, Vkontakte, Twitter). For example, Facebook public groups boast 72 communities dedicated to Stalin, from which 41 are Cyrillic. Totalizing more than $37 \mathrm{~K}$ members, these communities mainly promote and diffuse a glorious image of Stalin as a military leader and a great Chief of State. On the other spectrum of the debate, only one Cyrillic community, counting 345 members, is dedicated to the crimes of Stalin.

These statistics echo the broader situation in the Russian current perception of Stalin's role in the Great Patriotic War - according to recent polls of the Levada centre, the number of critics have steadily decreased during the 200os, to touch a "historical minimum" in May 2017 (only 12\% attributed to Stalin the USSR's giant human losses during the war, as compared to $34 \%$ in 1997). While the debate continues to prove highly polarizing on social media, it seems that the public opinion has reached a consensus on the topic.

\section{References}

\section{Blog Posts}

'abstract2001' (2010 April 14), "Stalin na avtoubouse" / "Stalin on the bus', Livejournal, $<$ http://abstract20o1.livejournal.com/1103966.html>, accessed April 17, 2018.

'antidogma' (2010 March 13), "Luzhkov i Stalin" / "Luzhkov and Stalin", Livejournal, $<$ http://ru-antidogma.livejournal.com/716617.html >, Link expired

Andrei Martianov, [gunter_spb]. Various posts, Livejournal. <http://gunter_spb.livejournal.com/>, accessed October 3, 2011

'avmalgin' (2010 April 17), "Dostoino vstretim generalissimusa." / "Let's Meet The Generalissimos With Honours." Livejournal, <http://avmalgin.livejournal.com/1913956. html>, accessed February 20, 2018

'bakushinskaya' (2010 April 17), "Pro partizan" / "About partisans", Livejournal, <http:// bakushinskaya.livejournal.com/326230.html>, accessed April 17, 2018. 
Dmitrii Lyskov. n.d. [_lord_]. Various posts, Livejournal. <http://lord_livejournal. com/>, accessed October 3, 2011. Journal deleted

"Dmitri Medvedev". 2012. October 30, 2012. Facebook account. <https://www.facebook. com/Dmitry.Medvedev/posts/10151092413876851>, accessed February, 20, 2018.

“drugoi" (2010 March 05), "Deti - eto nasche buduschee" / "Children are our future", Livejournal, <http://drugoi.livejournal.com/3196279.html>, accessed April 17, 2018. 'germanych' (2010 April 30), "Podarok veteranam" / "A gift to veterans", Livejournal, $<$ http://germanych.livejournal.com/198320.html>, accessed April 17, 2018.

'leonid_b' (2010 March 09), "Tipo tol'ko voprosy” / 'Kinda only questions”, Livejournal, <http://leonid-b.livejournal.com/667464.html>, accessed April 17, 2018.

'lex-kravetski' (2010 April 15), "Pro futbolki so Stalinym" / "On T-shirts with Stalin", Livejournal, <http://lex-kravetski.livejournal.com/294467.html>, accessed April 17, 2018.

"lord." (2011 February 28), "Avtobus Pobedy poiavitsia v Moskve k 9 Maia." / "The Bus of the Victory Will Appear in Moscou by the 9th May." Livejournal, February 28, 2011. Accessed February 20, 2018. <http://users.livejournal.com/_lord_/1551587.html> Journal deleted

"Mahabon." 2010. "Provokatsiya Luzhkova - plakati Stalina v Moskve." / "Luzhkov's Provocation - Stalin's Posters in Moscow." Livejournal, March 6, 2010. <http://rupolitics.livejournal.com/28423494.html>.

"Narodnii Komissariat Istoricheskoi Dostovernosti." / "People's Commissariat of Historical Truth." Livejournal. <http://ru_nkid.livejournal.com/>, accessed February 20, 2018 .

'nordman75' (2010 April 08), "My doljny vystoupit' protiv plakatov s izobrazheniem Stalina!" / "We need to step up against the images of Stalin!", Livejournal, <http:// nordman75.livejournal.com/517088.html>, accessed April 17, 2018.

'ru_politics' (2010 March 06), "Provokatsiia Luzhkova - portrety Stalina v Moskve" / 'Luzhkov's provocation - Stalin's portraits in Moscow', Livejournal, <http://ru-polit ics.livejournal.com/28423494.html>, accessed April 17, 2018.

'ru_politics' (2010 March 09), “Stalina zakazali” / 'Stalin was framed', Livejournal, <http://ru-politics.livejournal.com/28457864.html>, accessed April 17, 2018.

'ru_politics' (2010 February 18), “Leonid Gozman o Staline” / “Leonid Gozman on Stalin', Livejournal, <http://ru-politics.livejournal.com/28052206.html>, accessed April 17, 2018.

'sirjones" (2010 April 13), "Glamurnoe kiso negodue" / "Glamourous kittycat is angry", Livejournal, <http://sirjones.livejournal.com/1243033.html>, accessed April 17, 2018.

Stalinobus. n.d. Facebook. Accessed February 20, 2018. <https://www.facebook.com/ stalinobus>.

Stalinobus. n.d. Vkontakte. Accessed February 20, 2018. <http://vk.com/stalinobus >. 
Stalinobus. n.d. (@stalinobus) Twitter. Accessed February 20, 2018. <http://twitter. com/\#!/stalinobus $>$.

Stalinobus. n.d. <http://сталинобус.pф/> Link expired, <http://stalinobus.info/> Link expired, <http://stalinobus.su/> Link expired

"tema." 2018. "Velikii Stalin." / "Great Stalin." Livejournal, January 25, 2018.. <https:// tema.livejournal.com/2688494.html>, accessed March 5, 2018

Viktor Loginov. n.d. [viklamist]. Various posts, Livejournal. <http://viklamist.livejournal.com/>, accessed October 3, 2011.

'vsoloviev' (2010 March 04), "Prazdnik bez razdora" / "Celebration without quarrelling”, Livejournal, <http://vsoloviev.livejournal.com/229779.html>, accessed April 17, 2018.

'uskov' (2010, April 12), "Stalinou H*I" / "F*CK Stalin", Livejournal, <http://uskov.live journal.com/116289.html>, accessed April 17, 2018.

'uskov' (2010 April 15), "Merskii Stalin” / "Despicable Stalin”, Livejournal, <http://uskov. livejournal.com/116948.html>, accessed April 17, 2018.

'u-96' (2010 April 15), “Podbrosim ugol'ku” / 'Bring in some fire”, Livejournal, <http://u-96. livejournal.com/2094417.html>, accessed April 17, 2018.

\section{Other References}

Adler, Nanci. 2012. "Reconciliation with - or rehabilitation of - the Soviet past?" Memory Studies 5, 330.

Alexanyan, Karina. 2013. "The Map and the Territory: Russian Social Media Networks and Society." Ph.D. dissertation, Columbia University. Accessed February 2, 2014. $<$ http://academiccommons.columbia.edu/catalog/ac\%3A156925>.

Andreev, Dmitrii, and Gennadii Bordiugov. 2005. Prostranstvo pamiati: Velikaia Pobeda ivlast”|'The Space of Memory: The Great Victory and The Power. Moskva: AIRO-XXI).

Argumenty i fakty. 2013. "Stalin - samaia obolgannaia lichnost'." February 6, 2013. Accessed February 20, 2018. <http://www.aif.ru/culture/person/40216>.

Beaulieu, Anne. 2004. "Mediating Ethnography: Objectivity and the Making of Ethnographies of the Internet." Social Epistemology 18 (2-3): 139-163.

Berelowitch, Alexis. 2010. "Le soviétisme ordinaire." In Favarel-Gerrigues, Gilles and Rousselet, Kathy (eds): La Russie Contemporaine, 75-86. Paris: Fayard.

Bomsford, Falk and Andrei Bordugov. 2006. Nazrevshaia diskussiia. Nekotorye itogi obsuzhdeniia istorii Vtoroi Mirovoi Voiny (verbatim). Moskva: Obshchestvennyi Forum.

Chauvier Jean-Marie .1995. "Ex-UssR, C.E.I., Eurasie: dislocation ou re-union?” In Russie post-soviétique: la fatigue de l'histoire ?, edited by Garros Véronique, 39-65. Bruxelles: Edition Complexe.

ComScore. 2011. "ComScore Releases Overview of European Internet Usage in September 2011." Accessed May 1, 2012. < http://www.comscore.com/Press_Events/ 
Press_Releases/2011/11/comScore_Releases_Overview_of_European_Internet_ Usage_in_September_2011>.

ComScore. 2010. "Russia Has Most Engaged Social Networking Audience Worldwide." Accessed February 20, 2018. <http://www.comscore.com/Press_Events/Press_ Releases/2010/10/Russia_Has_Most_Engaged_Social_Networking_Audience_World wide>.

Daucé, Françoise, Myriam Désert, Marlène Laruelle, Anne Le Huérou, and Kathy Rousselet. 2010. "Les usages pratiques du patriotisme en Russie." Questions de recherche 32. Accessed March 2, 2013. <http://www.ceri-sciences-po.org/publica/qdr. htm>.

De Bruyn, Ditter. 2010. "World War 2.0: Commemorating War and Holocaust in Poland through Facebook". Digital Icons: Studies in Russian, Eurasian and Central European New Media 4: 45-62.

Digital Methods Initiative. 2010. "Historical Controversies Now." University of Amsterdam. Accessed February 4, 2014. <https://wiki.digitalmethods.net/Dmi/Old ControversiesNow>.

Dubin. Boris. 2009. "Vektory i urovni kollektivnoi identifikatsii v segodnyachnei Rossii." "Vectors and Levels of the Collective Identification in Modern Russia." Vestnik obschestvennogo mneniya/Bulletin of Public Opinion 2: 55-64.

Dubin, Boris. 2011. Rossiia nulevikh: politicheskaia kul'tura, istoricheskaia pamiat", povsednevnaia zhizn'/"Russia of the Year Two Thousand: Political Culture, Historical Memory, Everyday Life." Moscow: Rossiiskaya Politicheskaya Entsiklopediia.

Etkind, Alexander. 2009. "Putin's History Lessons." Project Syndicate, September 15. Accessed March 2, 2012. <http://www.project-syndicate.org/commentary/etkind7/ English >.

Etkind, Alexander. 2009. "Post-Soviet Hauntology: Cultural Memory of the Soviet Terror." Constellations 1 (16): 182-200.

Etling, Bruce, Karina Alexanyan, John Kelly, Robert Faris, John Palfrey and Urs Gasser. 2010. Public Discourse in Russian Blogopshere: Mapping Runet Politics and Mobilization. Harvard University: Berkman Center Research Publication.

Ferretti, Maria. 2002. "Le stalinisme entre histoire et mémoire: le malaise de la mémoire russe." Matériaux pour l'histoire de notre temps 68: 65-81.

Ferretti, Maria. 2005. "Neprimirimaia Pamiat': Rossiia i Voina. " "Irreconciliable Memory: Russia and the War." Neprikosnovennii Zapas / Reserve Stock 2:3: 40-41. Accessed May 5, 2012. <http://magazines.russ.ru/nz/2005/2/fere8.html>.

Forbes. 2013. "Kak milliarder Alexander Mamut proschitalsia sdelav stavku na ZhZh." March 12, 2013. Accessed March 17, 2015. <http://www.forbes.ru/kompanii/ internet-telekom-i-media/235330-kak-milliarder-aleksandr-mamut-proschitalsyas-investitsiya >. 
Garcia Cora, Angela, Alecea I. Standlee, Jennifer Bechkoff, and Yan Cui. 20og. "Ethnographic Approaches to the Internet and Computer-Media Communication.” Journal of Contemporary Ethnography 38: $5^{2}$.

Garde-Hansen, Joanne, Andrew Hoskins and Anna Reading. 20o9. Save As... Digital Memories. Hampshire: Palgrave Macmillan.

Gorman, Michael. 2011. “Medvedev's Blogging Bureaucrates: Official Models of Identity and Community in the New Media Age" [Conference Paper]. Virtual Russia: digital Space and Post-Soviet political culture, October 19-22. Norwegian University Center: Saint-Petersburg (Russia).

Gudkov, Lev. 2005. "'Pamiat' o voine i massovaia identichnost' rossiian."|“'Memory' of the War and Russians' Mass Identity." In 6o-letie okonchaniia Vtoroi mirovoi i Velikoi Otechestvennoi: pobediteli i pobejdennie v kontekste politiki, mifologii i pamiati / 6os Anniversary of the End of the Second World War and the Great Patriotic War: the victors and the vanquished in the political, mythological and memorial context. Edited by Falk Bomsdorf and Gennadii Bordiugov, 94-112. Moscow: Friedrich Naumann Foundation.

Hoskins, Andrew. 2011. " $7 / 7$ and connective memory: Interactional trajectories of remembering in post-scarcity culture." Memory Studies 4 (3): 269-280.

Hösler, Joachim. 2005. "Chto znachit 'Prorabotka proshlogo'? Ob istoriografii Velikoi Otechestvennoi voiny v sssR i Rossii”/“What does 'Memory work' mean? On the Historiography of the Great Patriotic war in the Uss and in Russia". Neprikosnovennii Zapas /Reserve Stock 2 (3): 40-41. Accessed May 5, 2012. <http://magazines.russ.ru/ $\mathrm{nz} / 2005 / 2 /$ he10.html>.

Izvestia. 2013. "Stalinobusy proedut 2 fevralia v Pitere, Chite i Volgograde." January 31, 2013. Accessed February 20, 2018. <http://izvestia.ru/news/543994\#ixzz2tmXELR2z>.

Kaelber, Lutz. 2010. "Virtual Traumascapes: The Commemoration of Nazi 'Children's Euthanasia' Online and On Site." Digital Icons: Studies in Russian, Eurasian and Central European New Media 4, 13-44.

Khapaeva, Dina. 1995. "L’Occident sera demain. " Annales. Histoire, Sciences sociales 6, 1259-1270.

Koltsova, Olessia, and Sergei Koltsov. 2013. "Mapping the public agenda with topic modelling: The case of the Russian Livejournal." Policy and Internet 5 (2): 207-227.

Komitet Pobeda. 200o. Ukase du Président de la Fédération de la Russie de 5 août 2000 n. 1441 « Sur le Comité russe d'organisation « Victoire» » August 5, 2000. Accessed February 20, 2018. <http://kremlin.ru/events/president/news/38875>.

Koposov, Nikolai. 2011. "Pamiat' strogogo rezhima. Istoriia i politika v Rossii”/“Memory of High Security. History and Politics in Russia." Moscow: Novoe Literaturnoe Obozrenie.

Krasnoboka, Natalya. 2002. "Real Journalism Goes Underground: the Internet Underground." The International Journal for Communication Studies 64 (5): 479-499. 
Kurland, Philip B., and Ralph Lerner, eds. 1987. The Founders' Constitution. Chicago: University of Chicago Press. <http://press-pubs.uchicago.edu/founders/>.

Latynina, J. 2010. “Kod dostupa." Ekho Moskvy, May 8, 2010. Accessed March 5, 2012. <http://www.echo.msk.ru/programs/code/677955-echo/>.

Lenta. 2012. "Polovina rossiian vyshla v Internet." Lenta.ru, June 2. Accessed June 15, 2012. <http://www.lenta.ru/news/2012/06/o2/seventy/>.

Levada. 2004. "Rossiiane o role Stalina v istorii nachei strany"/“Russians about Stalin's role in Russian history." December 12, 2004. Press-centre of Levada Centre, Polit.ru. Accessed February 20, 2018. <http://polit.ru/article/2004/12/21/stalin/>.

Levada. 2010. "Velikaia Otechestvennaia Voina v otsenkakh naseleniia"|“The Great Patriotic War in Population's Appraisals." June 6, 2018. Accessed April 4, 2012. $<$ http://www.levada.ru/press/2010061804.html>.

Levada. 2017. "Chislo kritikov roli Stalina v voine dostiglo istoricheskogo minimuma" / "The number of critics of Stalin's role in the War have hit an historical minimum." June 22, 2017. Accessed March 5, 2018. <https://www.levada.ru/2017/06/22/chislokritikov-roli-stalina-v-vojne-snizilos-do-istoricheskogo-minimuma/>.

Livejournal. 2012. "Avtobus Pobedy. Promezhutochnye rezul'taty."|"The Bus of The Victory. Preliminary Results." Livejournal, April 10, 2012. Accessed February 20, 2018. <http://ru-nkid.livejournal.com/21266.html\#comments >.

Livejournal. 2013. "Makety dlia aktsii Vernem Pobede Imia." January 18, 2013. Accessed February 20, 2018. <http://ru-nkid.livejournal.com/32129.html >.

Livejournal. 2013. "Press Reliz orgkomiteta aktsii Avtobus Pobedy." Livejournal, April 24, 2013. Accessed February 20, 2018. <http://ru-nkid.livejournal.com/2013/04/24/>.

Livejournal. 2013. "Stalinobus 2013." January 31, 2013. Accessed February 20, 2018. <http:// colonelcassad.livejournal.com/948429.html>.

Lonkila, Markku. 2008. "The Internet and Anti-military Activism in Russia." EuropeAsia Studies 60 (7): 1125-1149.

MacLeod, Heather. 2009. "Examining Political Group Membership on Livejournal." Digital Icons: Studies in Russian, Eurasian and Central European New Media 1 (1): $13-26$.

Maj, Anna, and Daniel Riha. 20o9. Digital Memories: Exploring Critical Issues (E-Book). Oxford: Inter-Disciplinary Press. Accessed February 20, 2018. <http://dspace.ut.ee/ bitstream/handle/10062/15379/Digital_Memory_e-book.pdf $>$.

Makarychev, Andrei. 2010. "Great Patriotic War Narratives in the Russian Cinema: Collective Self, Internal Others, and Dislocations of Identity." Russian analytical digest $89,2-5$.

McDaniel, Tim. 1996. The Agony of the Russian Idea. Princeton: Princeton University Press.

Nivat, Georges. 2008. "Russie. Eclats de mémoire." Le courrier des pays de l'Est 1067, 8-12. Nora, Pierre. 1984. Les Lieux de mémoire. La République. Paris : Gallimard. 
Novaia Gazeta. 2012. "Proigravshie pobediteli." November, 12 2012. Accessed February 20, 2012. <http://www.novayagazeta.ru/society/55377.html>.

Polian, Pavel. 2002. "La violence contre les prisonniers... de guerre soviétiques dans le III Reich et en USSR." in La violence de guerre, 1914-1945, Edited by Audoin-Rouzeau, Stéphane, Annette Becker, Christian Ingrao, Henry Rousso et al, 117-131. Bruxelles : Edition Complexe.

Postill, John, and Sarah Pink. 2012. "Social media ethnography: the digital researcher in a messy web." Media International Australia 145, 2.

Radio Liberty. 2015. "Russia Unveils Controversial Yalta Monument featuring Stalin." 5 February 2015. Accessed March 17, 2015. <http://www.rferl.org/content/russia-unveils-controversial-yalta-monument-featuring-stalin/26831980.html >.

RBC.Ru. 2010. "B. Gryzlov prizyvaet Iu. Luzhkova ne razmeschat' plakaty Stalina." Published March 5, 2010. Accessed February 20, 2018. <http://top.rbc.ru/society/ 05/03/2010/377383.shtml>.

Reuter, Ora John, and David Szakonyi. 2012. "Online social media and political awareness in authoritarian regimes [Working Paper]" (Basic Research Program at the National Research University Higher School of Economics). Accessed February 2, 2014. <http://www.hse.ru/data/2012/12/27/1304312632/10PS2012.pdf>.

Roginskii, Arseniï. 2009. "Mémoire du stalinisme." Le Débat 155, 119-130.

Rossiskaya Gazeta. 2010. "Byt' ili ne byt'?" 20 April, 2010. Accessed March 5, 2012. <http://www.rg.ru/2010/04/20/reg-dvostok/stalin.html>.

Rossiskaya Gazeta. 2010. "Na glavnoi ulitse Vladivostoka poiavilis' Stalin i marshaly pobedy." April 30, 2010. Accessed March 5, 2012. <http://www.rg.ru/2010/04/30/regdvostok/marshaly-anons.html>.

Rosbalt. 2010. "Meriia: stendy so Stalinym budut sviazany tol'ko s iubileem pobedy." February 19, 2010. Accessed March 5, 2012. <http://www.rosbalt.ru/moscow/2010/ 02/19/714411.html>.

Russian government website. 2009. "Pamiat' o natsional'nyh tragediiiah tak zhe sviaschenna, kak pamiat' o pobedah." Kremlin.ru, October 20. Accessed June 15, 2012. $<$ http://kremlin.ru/transcripts/5862>.

Russian University of Commerce. 2011. Conference 'Stalin's role in the War." May 4, 2011. Accessed February 20, 2018. <http://old.rsute.ru/News/Pages/КОНФЕРЕНЦИЯДИСКУССИЯ.aspx> (Link expired).

Rutten, Ellen. 2010. "Web Wars: Digital Diasporas and the Language of Memory (An Announcement of the HERA Research Project, University of Bergen)." Digital Icons: Studies in Russian, Eurasian and Central European New Media 4, 171-176.

Scherrer, Jutta. 2007. “Anciens/Nouveaux lieux de mémoire en Russie.” Outre-terre 19, 187-194.

Sherlock, Thomas. 2011. "Confronting the Stalinist Past: The Politics of Memory in Russia." Washington Quarterly 34 (2): 93-109. 
Smith, Kathleen. 2002. Mythmaking in the New Russia. Politics and Memory During the Eltsin's Era. Ithaca: Cornell University Press.

The Moscow Times. 2015. "Museum Honoring Stalin's Legacy Set to Be Open in Russia." March 11, 2015. Accessed March 16, 2015. <http://www.themoscowtimes.com/article. php?id=517314>.

Tretyakov, V. 2010. "Voina so Stalinym, Pobeda - bez nego?” Komsomol'skaya Pravda, May 8, 2010. Accessed March 5, 2012. <http://www.kp.ru/daily/24486/642485/>.

Tumarkin, Nina. 1994. The Living and The Dead. The Rise and Fall of the Cult of World War II in Russia. New York: Basic Books.

Van Dijck, José. 2010. "Flickr and the culture of connectivity: Sharing views, experiences, memories." Memory Studies 4, 401-415.

Veselova Alexandra. 2004. "Otechestvennaia Istoriia glazami starsheklassnikov." I "National History Seen by Senior Pupils." Otechesvennie Zapiski / Annals of the Motherland 5 (19). Accessed May 5, 2012. <http://magazines.russ.ru/oz/2004/5/2004_ 5_9.html>.

Werth Nicolas. 2004. "La société et la guerre dans les espaces russes et soviétique, 19141946." Histoire, économie \& société 2, 191-214. 
PART 3

Popular Culture and Its Embeddedness in Politics 